\title{
An Examination of Student Club Activities from the Perspective of School Principals and Teachers
}

\author{
Ikram Çınar ${ }^{1, *}$ \\ ${ }^{1}$ Department of Educational Sciences, Faculty of Education, Kafkas University, Turkey \\ *Correspondence: Department of Educational Sciences, Faculty of Education, Kafkas University, Turkey. E-mail: \\ ikramcinar@gmail.com
}

Received: June 21, 2019

Accepted: July 13, 2019 Online Published: August 25, 2019

doi:10.5430/wje.v9n4p123

URL: https://doi.org/10.5430/wje.v9n4p123

\begin{abstract}
In this study, the effects of student club activities in high schools in Kars province, Turkey on the development of students' social skills, democracy and governance skills, recreation education and community service skills were examined. The qualitative research technique was used in the study and data were collected with the semi-structured interview technique. The data were obtained from 8 school principals and 12 club advisors from different school types determined with the maximum variation sampling method. According to the results, the educators in the sample concluded that the student clubs achieved their objectives in the theme of democracy and governance skills but were not effective in the other themes. The reasons for this ineffectiveness emerged as deficiencies in the physical environment in the schools, lack of time allotted for activities, excessive numbers of students in the clubs and unwillingness of teachers with regard to club activities. It was suggested that if the choice of whether or not to engage in club activities is left to students, the activities in clubs will become more attractive and thus their effectiveness will increase.
\end{abstract}

Keywords: student clubs, democracy education, recreation education, community service, school principal

\section{Introduction}

\subsection{Introduce the Problem}

Education is a process by which the knowledge and skills required by humans for staying alive and making new contributions to culture are acquired. Nowadays, besides a person's survival, aims such as participating in social life, realising oneself as a healthy and balanced individual, and being a part of humanity have also become goals of the education process.

Although it is the family that is primarily responsible for education, the emergence of the nuclear family and the employment of women outside the home following the Industrial Revolution paved the way for the development of schools and finally for the emergence of compulsory and mass school education. As an "education factory", the school now produces "citizens" who have technical skills. This production is carried out in such a way that students can use scientific knowledge for solving the problems they encounter by the use of scientific methods and techniques.

School education teaches students to deal with all problems that they may be faced with in order to be successful in life. However, this situation results in learning subjects to be continued outside lessons. Certain subjects can be learned, indeed can only be learned, outside school. Student clubs are also utilised for continuing school and extracurricular learning activities.

A student club is a temporary group formed with the aim of enabling students to engage in intramural and extramural activities in scientific, social, cultural, artistic and sporting fields throughout their learning. The student club is a school organisation or student group formed by students with a common interest in a certain activity (Bakırcioğlu, 2016, p. 91).

The beginning of student clubs in Turkey may have been initiated with the establishment of the Scouting Organisation in 1910. Following the foundation of the Republic in 1923, educational clubs were set up in high 
schools and were regarded as part of democracy education. Over time, their functions were diversified and their curricular content was enriched. In order for students each to become active citizens of the Turkish Republic, their intensive participation in school life was aimed for. In 1927, groups such as the following were set up for students to learn about democracy (Altunya, 2009, p.78): The Hygiene and Health, Preservation of School Items, Good Manners and Courtesy, Assistance for Needy Students, Travel and Research, and Cooperative Branches.

Legislation by the Ministry of National Education (MEB) related to student clubs is fairly dynamic and is frequently changed (MEB, 1983; MEB, 1995; MEB, 2005; MEB, 2008; MEB, 2017). The name and model of club activities has also been changed: club activities were named "social activities" (1927), "educational branch" (1983) and finally "student club" (2005). It is seen that as organisational models, while student clubs were in the form of in-class groups at the beginning, they were based on the committee type after 2005 and are now based on the non-governmental organisation (NGO) model.

Student clubs are assumed to be democratic mass organisations. Considering clubs and the way they are run, it can be understood that they have an organisational model similar to an association, trade union or political party. A club has committees such as a general assembly, management and audit committees, and a board of club chairmen. According to the regulations, elections are held for these committees and democratic procedures are learnt through experience. Club elections and in general, operations are prepared in a similar way to the law of associations. With the legal reforms carried out in recent years, however, student committees in clubs have been removed, and a good deal of authority has been invested in the club chairman. In this way, participatory democracy in clubs has been compromised.

Student clubs encounter numerous problems in their operation. Some of these problems are natural problems originating from the characteristics of club operation. Clubs have the structure of a temporary organisation set up at the beginning of each academic year and disbanded at the end of the year. Even if students who conduct club activities devote their entire school life to the relevant club, they will eventually graduate and leave within a few years. Students are generally active in a different club each year. This discontinuity hinders institutionalisation. Member circulation prevents a club from being an "organisation" as the term is defined in the literature. Under the effect of frequent changes of members, an organisational or institutional culture cannot be created, organisational traditions and habits do not emerge, and clubs cannot become a centre for goals and ideals. When there is no cause, members' levels of commitment to the club also remain weak.

\subsection{Functions of Student Clubs}

Student clubs in primary and secondary schools in Turkey are organisations established within schools, each with an administrative, educational, social and democratic substructure, in which students conduct their activities under the supervision of an advisor. Since student clubs do not depend on different environments outside the classroom or even outside school in order to perform their activities, they bring variety to school education and increase students' engagement in school. Student clubs follow a method based on teaching their functions by using social skills. When the literature on this subject is examined in the context of Turkey, it is seen that clubs perform their duties by carrying out four functions.

\subsubsection{Fostering Social Skills}

The aim of education is to prepare a child for his/her roles in life. The school also asserts that it will accomplish this. By creating student clubs, the school is there to enable students to acquire and develop skills related to social life that they will not be able to learn in the classroom. With the competencies that they will acquire in fields such as social, economic, cultural, political and health areas, students will gain skills that enable them to live freely and to realise themselves (Erginsoy Osmanoğlu \& Kaya, 2013). Student clubs are a good environment for this function of education to be carried out.

\subsubsection{Fostering Democracy Education and Governance Skills}

The contribution of student clubs is especially great with regard to democracy education. By means of the preliminary meetings, discussions and exchanges of views, group activities, research and elections conducted during club activities, students in the same age group gain democratic attitudes and behaviours. The effective guidance of teachers during the club processes enables students to acquire a democratic culture and to gain leadership skills.

Furthermore, democratic standards and opportunities to engage in public management increase. In addition to this, the decrease in the state's share in the economy after neoliberal economo-political practices gained sway, and the increase in tasks that need to be carried out due to the state's withdrawal from the public arena, have made community service essential. Services still need to be provided in the areas vacated by the state. Moreover, as a result 
of the development of democratic understanding, it was concluded that the NGOs also needed to take part in the public's self-governance and this encouraged the adoption of an understanding of governance in which the state shares its administration activities with the NGOs. All these developments make it necessary for future generations to learn to be organised with the NGO model and to learn both how to participate in administration and to engage in community service without expecting anything in return. By considering these two developments, education systems have begun to make an effort to educate students who can acquire the necessary governance skills for such a society. Every student club aims to operate as a miniature example of a democratic society based on governance skills.

\subsubsection{Recreation: Teaching Students How to Use Leisure Time Correctly}

Clubs contribute to students' physical and mental development and give an opportunity for their development. People also live their lives outside work, and recreational skills are important. Recreation activities are activities conducted individually or in a group, which, by good planning of one's time, enable people to renew themselves physically and mentally during the leisure time that emerges outside work and obligatory duties, which are performed voluntarily, and which provide a feeling of personal satisfaction (Karaküçük, 1995, p. 48). Student clubs provide the opportunity for students to apply and adapt the things they have learnt at school or outside school to their daily lives (Çelebi, 2016).

Recreation education and democracy education are similar to each other. More than the mere transfer of information to people with democracy education, enabling them to perceive democratic principles, thereby making these an assimilated part of their personalities, and the effort to raise young people for a democratic order, are important contributions of recreation education to democracy (Kılbaş, 2010, p. 25).

One of the important functions of schools in education is to bring children of the same age together and create social networks by the formation of groups, thereby preparing them for their roles in adulthood by their involvement in cooperation, solidarity or rivalry and competition. Student clubs provide an ideal environment for this purpose. With the skills that they gain in this environment, by spending a pleasant and enjoyable time and acquiring a culture of holiday and tourism, they become integrated into society as joyful, lively, positive people with a sense of humour.

\subsubsection{Fostering Civil Society Skills: Community Service}

Community service is the performing of temporary tasks by students within the scope of social responsibility, aimed at solving an ongoing problem in social life and eliminating troublesome situations of individuals and groups, without expecting anything in return. The course named Community Service Practices, which was added to the curriculum by the Turkish Ministry of National Education in 2005 and to the teaching programmes of Education Faculties in Turkish Universities in 2006, teaches students how they can serve the community.

The premise of the Community Service Practices course is that since, in the near future, intelligent machines will be able to do a lot of the work that people do, people will live on by spending less time at work. People's leisure time outside work is increasing. Therefore, they can make use of this leisure time by serving the community. In this way, not only will the state's social spending decrease, but also, people's lives will become more meaningful. The education for this should also be provided in schools.

\subsection{Aim of the Study}

Revealing the problems stemming from the implementation of student club activities in high schools and developing solution proposals for obtaining effective outcomes from the activities provide application data for rule makers and curriculum developers. Accordingly, the aim of this study is to examine the views of school principals and teachers regarding the effectiveness of student club activities in high schools in the province of Kars, located in the North-east of Turkey. With this aim, answers were sought to the following questions:

What are the views of school principals and teachers with respect to student clubs' effectiveness in fostering

a. social skills,

b. democracy and governance skills,

c. recreational skills and

d. community service skills?

\section{Method}

The research data were obtained by using the semi-structured interview technique, which is one of the qualitative 
research methods, based on the explanations given by Creswell (2013). The study was conducted with teachers who implement activities related to student clubs in schools and with the school principals who prepare suitable environments for them. In order to learn their approaches to the subject and the obstacles that they encounter, in-depth analyses are necessary. For this reason, the phenomenology design was used in the study. The phenomenology design focuses on phenomena of which we are aware, but about which we do not have an in-depth and detailed understanding (Yıldırım \& Şimşek, 2016, p. 69).

\subsection{Participants}

When determining the participants, educators with personal experience related to the studied process were taken into consideration. The study group was determined with the maximum variation sampling method. In the maximum variation sampling method, the aim is to create a small sample and to increase the variety of individuals related to the studied situation within this sample. In doing this, the aim is not to generalise, but to determine whether there are similarities among individuals with different characteristics with regard to the studied situation, and to reveal different dimensions related to the studied situation (Yıldırım \& Şimşek, 2016, p. 119). For this reason, with the idea that the views of teachers and managers in different branches and employed in different school could display maximum variation, this sampling method was selected. Therefore, 8 school principals and 12 teachers specified in Kars made up the study group. 8 of these were female and 12 were male. The educators in the study group were coded as P1, P2, .. P20, and their personal characteristics are shown in Table 1.

Table 1. Personal Characteristics of Study Group

\begin{tabular}{lllllll}
\hline $\begin{array}{l}\text { Code } \\
\text { No. }\end{array}$ & Gender & Duty & Seniority & $\begin{array}{l}\text { Age } \\
\text { Group }\end{array}$ & Branch & $\begin{array}{l}\text { High School } \\
\text { Type* }\end{array}$ \\
\hline P1 & Male & Principal & $11-15$ years & $36-42$ & Social Sciences & RVH \\
P2 & Female & Teacher & $1-5$ years & $22-28$ & Social Sciences & RVH \\
P3 & Male & Teacher & $1-5$ years & $22-28$ & General Skills & RVH \\
P4 & Female & Teacher & 6-10 years & $29-35$ & Social Sciences & RVH \\
P5 & Female & Principal & 16 years and over & $43-49$ & Social Sciences & AH \\
P6 & Male & Principal & $11-15$ years & $36-42$ & Social Sciences & AH \\
P7 & Male & Principal & 16 years and over & Over 50 & Philosophy-Theology & SH \\
P8 & Male & Principal & 16 years and over & $43-49$ & Philosophy-Theology & SH \\
P9 & Female & Teacher & $11-15$ years & $43-49$ & Science & VTH \\
P10 & Male & Teacher & $1-5$ years & $29-35$ & Science & VTH \\
P11 & Female & Teacher & $1-5$ years & $29-35$ & Science & VTH \\
P12 & Male & Principal & 16 years and over & Over 50 & Philosophy-Theology & VTH \\
P13 & Male & Principal & $1-5$ years & $36-42$ & General Skills & VTH \\
P14 & Male & Principal & $1-5$ years & $29-35$ & Science & VTH \\
P15 & Female & Teacher & $11-15$ years & $29-35$ & Social Sciences & RVH \\
P16 & Female & Teacher & $1-5$ years & $29-35$ & Science & SH \\
P17 & Male & Teacher & 6-10 years & $29-35$ & Science & SH \\
P18 & Male & Teacher & 6-10 years & $29-35$ & General Skills & FAH \\
P19 & Female & Teacher & 6-10 years & $36-42$ & Social Sciences & FAH \\
P20 & Male & Teacher & $11-15$ years & $36-42$ & Social Sciences & AH \\
\hline
\end{tabular}

*RVH: Religious Vocational High School, a high school where religious education is conducted

*AH: Anatolian High School, a high school primarily giving education in English

*SH: Science High School, a high school primarily giving education in Science

*VTH: Vocational-Technical High School

*FAH: Fine Arts High School

\subsection{Data Collection Tool}

The research data were gathered by means of a semi-structured interview form. Before the interview form was prepared, a review of the literature related to student clubs was carried out, after which the interview form was prepared. In the first part of the interview form, personal information related to the participants (gender, type of duty, 
seniority, age, branch and type of high school employed at) was included. In the second part of the interview form, five questions were included with which the teachers and school principals could reveal their views regarding the functioning of student clubs. Four of these questions were based on the four functions of student clubs, and were determined by considering that one question would be sufficient for each function. The fifth question, however, was asked in order to determine suggestions. In order to broaden the responses, 9 probe questions were also asked. To ascertain whether the questions were fit for the purpose or not, the views of two experts from the Education Faculty were obtained. Moreover, to check whether the questions were clear and understandable or not, a pilot implementation was conducted with three school principals. After the following questions had been included in the form and the necessary permission had been obtained, the participants were interviewed.

1) What kind of skills do students gain from student clubs in order for them to establish good relationships with other people?

Probe questions:

a. What kind of environments are there in clubs in which students can learn to behave with respect for each other?

b. What kind of practices are there in clubs with which students can learn the rules of good manners and courtesy?

c. Are there practices with which students can develop the skill of establishing equal relationships with others?

2) Which democratic processes are experienced in student clubs for fostering democracy skills?

Probe questions:

a. What kind of election practices are there for choosing managers?

b. What kind of practices are there for decision-making?

c. Which arrangements are there for developing those with leadership qualities?

3) Which recreational skills do student clubs foster?

Probe questions:

a. What kind of options are offered in clubs for students to make use of their leisure time?

4) Do student clubs enable students to acquire the skill of determining society's socio-economic problems?

Probe questions:

a. What kind of practices do clubs possess that enable students to gain the skill of awareness of society's socio-economic problems?

b. Do student clubs foster the ability to prepare projects for solving socio-economic problems?

5) If you were required to reorganise student clubs, what revisions would you make?

\subsection{Data Collection and Analysis}

The data were gathered in accordance with the interview form in April 2018 by conducting face-to-face interviews with the participants (school principals and teachers) and by taking notes on the interview form, and the interviews held lasted an average of 40 minutes each. Some teachers and managers wished to fill in the interview form in writing and so the form which included the questions was given to them and taken in written form. At the end of the interview, it was ascertained whether or not the statements had been clearly understood by reading the notes taken on the form to each participant.

In the analysis of the data obtained, descriptive and content analysis were used. Before the data were analysed, each interview form was coded as P1, P2, .. P20. Then, the statements on the interview form were examined by the researcher and codings of the statements were made depending on their content. Themes were created by taking the contents of these codes into consideration. Frequencies were calculated with regard to the statement frequency for each theme and code. Statements expressed individually by the participants were included.

An attempt was made to ensure the validity and reliability of the study by obtaining expert views at the creation stage of the interview form, conducting a preliminary interview with two school principals, obtaining confirmation by the participants as to whether or not the notes taken on the interview form had been correctly understood, separate coding of the data by another academician and comparison of the codes, and inclusion of the statements expressed individually by the participants one by one as direct quotes. 


\section{Findings}

In this study, in which the effectiveness of student clubs has been researched, the views of the participants are summarised below. The themes of the research are the themes of fostering social skills, democracy and governance skills, recreation and community service.

\subsection{Theme of Fostering Social Skills}

Among the educators participating in the study, 7 participants expressed positive views related to whether or not student clubs achieved their aim of fostering social skills, while 13 participants expressed negative opinions. With regard to the variables, only the four educators with 16 or more years of seniority all stated that they had negative views related to clubs' ability to foster social skills. Those expressing favourable views stated that clubs enabled students to acquire skills such as socialisation (P1, P17), improvement in self-confidence (P1, P17), respectful behaviour towards others (P2, P4, P9, P10), development of a consciousness of helping each other (P2, P6, P9, P14), learning courtesy and good manners (P3, P10, P14), improvement in communication skills (P5, P10, P14, P17), being sincere (P6, P10, P14) and being sharing (P6). Those with unfavourable views, however, objected because they believed club activities were unproductive (P7) or fatiguing (P8). P15 stated that student club activities were conducted on paper merely to make do, and that this was why they did not achieve their aim. P19 said that since students regarded club activities as an obligatory duty, the activities were perceived unsympathetically and students did not participate in them voluntarily. Table 2 includes the content analysis results related to clubs' fostering of social skills.

Table 2. Content Analysis Related to Theme of Fostering Social Skills

\begin{tabular}{ll}
\hline Fostering Social Skills & F \\
\hline Behaving respectfully towards each other & 4 \\
Developing a consciousness of helping each other & 4 \\
Acquiring ability to communicate with different people & 4 \\
Being sincere with others & 4 \\
Learning courtesy and good manners & 3 \\
Socialisation of students & 2 \\
Developing self-confidence & 2 \\
Learning to share & 1 \\
\hline
\end{tabular}

As can be seen in Table 2, "behaving respectfully towards each other", "developing a consciousness of helping each other" "acquiring ability to communicate with different people" and "being sincere with others" were most frequently mentioned with respect to the theme of fostering social skills.

In response to the question, "what kind of activities are carried out?" in the name of fostering social skills, 10 participants stated that no activities were carried out. Those conducting activities, however, considered that visiting elderly people staying in nursing homes for the purpose of Community Service Activities contributed to students' establishment of good relations with people outside school (P2, P3, P6, P17).

In the responses to the question, "which are the skills that club activities foster in students?" it was emphasised that club activities enabled students to acquire skills such as belonging to a group, developing a feeling of responsibility, providing an environment for expressing oneself (P1, P10, P19), acquiring good manners, being tolerant, carrying out the duties given (P2, P6, P9, P17), developing the skill of speaking and listening (P3) and developing one's personality (P7). According to those expressing these opinions, in schools conducting club activities, clubs enable students to achieve educational goals. However, P8 said, "Club activities are regarded as fatiguing by schools. Club activities need to be conducted on a voluntary basis." Also, P18 expressed that view that "Due to students' obligation to participate in clubs, they regard group activities as an unnecessary burden, and so the clubs cannot achieve their objectives."

Participants P8, P18 and P19 offered suggestions, stating that the system needed to be improved. In their opinion, if club activities are made voluntary instead of compulsory, club numbers are decreased and social awareness is managed in a constructive way, these activities will become more effective and productive.

\subsection{Democracy and Governance Skills}

This theme is concerned with students' acquisition of democratic skills by means of student clubs and with their success in achieving an understanding of governance. The participants stressed that for this theme, club activities 
were more functional in nature. While 15 participants expressed positive views with respect to this theme, 5 participants had negative opinions. No significant differences were found with regard to the age, gender or seniority variables. While P5, P8, P9, P11 and P20 said that there were no activities related to this theme in their schools, and problems stemming from teachers were mentioned, P8 stating that on account of pressure and inducements, the activities did not progress under democratic conditions, P9 and P18 reporting that due to teacher-centeredness, students were not able to be active, and P20 mentioning the fact that "the democratic process was applied only in the first meeting, while at other times, only formalities were carried out." While P12 expressed a positive view, he indicated that "at the general meeting, in which a student from every class was present, students from higher grades and older children who were repeaters had a negative effect on the system." Table 3 includes the content analysis results related to democracy and governance skills.

Table 3. Content Analysis Related to Theme of Democracy and Governance Skills

\begin{tabular}{ll}
\hline Democracy and Governance Skills & F \\
\hline Assimilating the democratic process & 6 \\
Learning leadership & 5 \\
Learning how to hold an election & 4 \\
Learning how to vote & 2 \\
Learning how to persuade & 2 \\
Learning how to debate & 2 \\
Learning how to make decisions within democracy & 2 \\
Perceiving the logic of democracy & 1 \\
Being on equal terms with others & 1 \\
Indirect learning of election preparations such as posters & 1 \\
and brochures & \\
Abiding by majority decisions & 1 \\
\hline
\end{tabular}

Table 3 reveals that for this theme, participants highlighted "assimilating the democratic process". Other prominent views were "learning leadership" and "learning how to hold an election".

In the context of clubs' fostering of democracy and governance skills in students, the participants expressed more optimistic views. They stated that the clubs served their purpose because club managers and class representatives' were chosen by vote, elections were based on persuasion and decisions on majority views, communication was carried out in a democratic environment, and leadership skills were developed in students.

The participants' suggestions for developing the system with regard to this to this theme also reveal why the system does not operate adequately. P2 suggested that "sufficient opportunities and possibilities should be provided for students to express their ideas, and they should not be reprimanded or humiliated on account of their ideas." In addition to this view, P1 stated that "students should be encouraged to negotiate, decisions should be made based on logical evidence and scientific data, views of the minority should not be ignored against those of the majority, and provision should be made for evaluating those views as well." Pointing out that the obligation for every student to belong to a club made the clubs crowded, P10 and P14 stated that large halls needed to be allocated for meetings.

\subsection{Recreation}

Another aim of club activities is to teach students how to spend their time outside lessons or work by carrying out activities for self-improvement. Regarding whether or not club activities achieved this aim, 14 participants expressed negative views, while 6 gave positive opinions. No significant differences were found regarding the other variables. Those who expressed negative views considered that "If club activities were conducted to suit their purpose, they could foster this skill." They put forward the view that the clubs' failure to conduct cultural, artistic or sporting activities was an obstacle to this. Table 4 includes the content analysis results related to the theme of recreation. 
Table 4. Content Analysis Related to Theme of Recreation

\begin{tabular}{ll}
\hline Recreation & F \\
\hline Choosing trip destinations & 1 \\
Social activities & 1 \\
Artistic activities & 1 \\
Cultural activities & 1 \\
Sporting activities & 1 \\
\hline
\end{tabular}

Suitable places and times do not exist in schools for the acquisition of recreational skills. Club activities are conducted outside lesson times, and due to double-shift schooling(note 1) in Turkey, schools remain occupied throughout the day. When children come out of their half-day lessons, they go home and have to spend the rest of the day in their homes. Therefore, education for spending productive and quality time is not provided at school.

Stating that "The biggest obstacle to learning how to make use of leisure time is the fact that nothing attracts students' attention other than smart phones and telephone games. It is very difficult to direct them towards another hobby or towards reading", P9 expressed his hopelessness. P12 was more optimistic: "Sporting students can be enabled to acquire sporting skills, even if limitedly. If such activities are evaluated with performance scores, it might be an incentive." P3 suggested that "Allowing students to engage in enjoyable activities by reducing the number of lessons, and highlighting voluntariness rather than obligation, will make them successful."

The participants' suggestions were for schools to proceed to full-day education, to increase leisure time by reducing the number of lessons, and to increase the number of chess rooms, sports areas such as tennis and football courts, and multi-purpose meeting rooms. Another suggestion was that recreational activities could be given scores.

\subsection{Community Service}

One of students' community service skills is to begin initiatives for solving a problem of the community without expecting anything in return. Regarding the effectiveness of club activities for fostering this skill in students, 4 participants expressed positive views, whereas 16 of them gave negative opinions. Those who reported positive views were participants who were principals and male. One of the reasons given by those with negative views was that "high-level skills such as preparing projects are above the level of the students" (P1, P2, P3). The reasons for negative views expressed by other participants were shown to be that club activities were not given importance at school (P4), that the lesson load did not leave time for club activities (P15, P16, P17), and that carrying out projects was expensive (P8). Table 5 includes the content analysis results related to the theme of community service.

Table 5. Content Analysis Related to Theme of Community Service

\begin{tabular}{ll}
\hline Community Service & F \\
\hline Helping the poor & 3 \\
Dealing with society's problems & 2 \\
Gaining awareness & 1 \\
Developing projects & 1 \\
\hline
\end{tabular}

Participants who expressed positive views stated that they were able to conduct successful activities in clubs. P6 and P10 indicated that that they organised campaigns for book and clothing aid for needy students both at home and abroad, and that students acquired the quality of sharing. P10 added that skills like awareness and sensitivity developed in students. P13 stated that the capacity for problem-solving and generating solution options also increased in students. P8 put forward the view that "If project-based teaching is implemented, clubs can also generate projects. However, projects also involve financial burdens. Therefore, institutions such as parent-teacher associations, trade unions, chambers of commerce and municipalities need to support these projects." P9 said that "I do not believe that students are interested in society's socio-economic problems. Fostering skills such as these can perhaps be enabled by also including families in the same training."

While gathering the data, one of the questions asked was "If you were required to reorganise student clubs, what revisions would you make?" Apart from P6 and P16, all participants expressed opinions. The shortest answer was given by P11: "Everything." A summary of the views of the other participants is as follows: Participation in clubs should not be compulsory, students and advisers should be chosen from among volunteers, clubs should be more functional and their relationship with daily life should be closer, clubs should focus on fostering skills that students 
will use in their lives outside school, advisers should be paid a separate fee for their guidance, club activity plans should be created by students, subjects should be included in which information technologies can be used effectively and which can generate software, teachers should be given more information about club activities, and lesson time should be allocated to club activities. As discussed below, these suggestions have also appeared as problems in certain studies.

\section{Discussion and Conclusion}

Student clubs are educational institutions belonging to schools that deal with school as real life and that within this realism prepare students for their future adulthood roles and provide them with an environment for organisational activities. Student club rules are established with the understanding that these activities should have an organisational structure. With club activities, the aim is for students who learn democratic knowledge and skills to discover the democratic country of the future. It is intended that by being organised as club members and working in an organised way, students will be prepared for the democratic organisational roles they will undertake in the future.

Participants in this study reported that for the themes other than that of democracy and governance, clubs did not have activities in line with their functions. Certain studies conducted on student clubs in Turkey have reached similar conclusions: that despite their efforts, student clubs were not able to achieve their aims. This is a serious deficiency. The principal reasons for this were that teachers did not make enough effort towards club activities (Arslantaş, 1989, p. 118; Arabac1 \& Akgül, 2011, Akay, 2012), that teachers did not have adequate knowledge and skills related to club activities (Arslantaş, 1989, p. 115; Koçinali, 2008, p. 177; Çınar, 2012), and that clubs were not designated according to students' needs (Arabacı \& Akgül, 2011).

The research results reveal that since participation in club activities is compulsory for all students, students are obliged to join clubs that they do not wish to. This paves the way for unwillingness, lack of motivation and inefficiency in club activities. The underlying reason for this was revealed to be a lack of physical space for conducting activities in schools and teachers' inadequate knowledge related to club activities.

Community service is an area with many problems; there are problems stemming from unwillingness of school administrations, from uncertainty about the legal situation and from the implementations. Reflected in research, these problems are listed as follows: the stakeholders in education (school management, teachers and parents) do not believe in the benefits of club activities (Çınar, 2012; Onay \& Gelen, 2013), the school management does not look positively on activities outside school (Arabacı \& Akgül, 2011; Çınar, 2012; Çelebi, 2016), a specific lesson time is not allotted to club activities (Arslantaş, 1989, p. 115; Koçinali, 2008, p. 177; Çınar, 2012), activities cannot be conducted outside school due to the high numbers of students (Onay \& Gelen 2013, p. 641), school facilities are inadequate due to conditions such as an excessive number of students for activities and unsuitability of activity areas (Çınar, 2012; Onay \& Gelen, 2013; Gömleksiz \& Kılınç), lack of importance given to clubs, administrative problems and personal reasons (Akar \& Nayir, 2015). The results of this study reveal that the problems that existed in previous years have not been eliminated.

Changes in student club regulations are made in parallel with the development of democracy in the country and with the adaptation of the Turkish education system to the body of educational knowledge as a candidate for EU membership. However, the studies made reveal that the inadequacy of the regulations, the lack of time and activity areas in schools, the insufficient knowledge of teachers and managers about clubs and the unwillingness for conducting activities reduce the effectiveness of clubs. The suggestion may be put forward that if students are left free to engage in club activities, the numbers of students in clubs will fall to a reasonable number and in this way, the clubs will be more effective.

\section{References}

Akar, F., \& Nayir, K. F. (2015). Eğitim kurumlarındaki sosyal kulüplerin etkililiğinin incelenmesi: Uygulamada değişim ihtiyacı. Pegem Ĕ̈itim ve Öğretim Dergisi, 5(2), 167-186, http://dx.doi.org/10.14527/pegegog.2015.009

Akay, S. (2012). Öğretmenlerin sosyal kulüp çalışmalarına yönelik tutumları ve bu çalışmalarda karşılaşılan sorunların incelenmesi (Gediz ilçesi örneği). Yüksek lisans tezi. İstanbul: Yeditepe Üniversitesi.

Altunya, N. (2009). Millî eğitimde Mustafa Necati dönemi. İstanbul: Uygun Basım.

Arabac1, İ. B., \& Akgül, D. (2011). İlköğretim okulu öğrencilerinin sosyal kulüp etkinlikleri konusundaki görüşleri: Bitlis ili örneği. (Bildiri). 5th International Computer \& Instructional Technologies Symposium. 22-24 
September, Elazığ. Firat Üniversitesi.

Arslantaş, Ö. (1989). İlkokullarda eğitsel kol çalı̧̧malarında karşılaşılan sorunlar (Yüksek lisans tezi.). Adana: Çukurova Üniversitesi.

Bakırcıoğlu, R. (2016). Ansiklopedik eğitim ve psikoloji sözlü̆̆̈̈. Genişletilmiş ikinci baskı. Ankara: Anı Yayıncılık.

Creswell, J. W. (2013). Araştırma deseni, nitel, nicel ve karma yöntem yaklaşımları. (Çev. S. B. Demir), Ankara, Eğiten Kitap Yayınları.

Çelebi, M. (2016). Recreational program implementations in education (Learning by living in community service). International Journal of Social Science Research, 5(1), 33-44.

Çınar, İ. (2012). Öğrenci kulüpleri ve demokrasi kültürü. Ankara: Ütopya Yayınları.

Erginsoy Osmanoğlu, D., \& Kaya, H. I. (2013). Öğretmen adaylarının yükseköğretime dair memnuniyet durumları ile öznel iyi oluş durumlarının değerlendirilmesi: Kafkas üniversitesi örneği. Kafkas Üniversitesi Sosyal Bilimler Enstitüsü Dergisi, Sayı 12, 45-70.

Gömleksiz, M. N., \& Kılınç, H. H. (2015). Ortaokullarda sosyal kulüp etkinlikleri kapsamında yapılan toplum hizmeti çalışmalarına ilişkin öğretmen görüşleri. Turkish Studies. International Periodical fort he Languages, Literature and History of Turkish or Turkic, 10(3), 495-512. http://dx.doi.org/10.7827/TurkishStudies.7978

Karaküçük, S. (1995). Rekreasyon: Kavram, kapsam ve bir araştırma. Ankara: Seren Matbaacılık.

Kılbaş, Ş. (2010). Rekreasyon: Boş zamanı değerlendirme. Ankara: Gazi Kitabevi.

Koçinali, A. (2008). Kocaeli ili Gebze ilçesindeki endüstri meslek liselerinde öğrenim gören öğrencilerin eğitsel kulüplere baklşı (Yüksek lisans tezi). İstanbul: Yeditepe Üniversitesi.

MEB (Millî Eğitim Bakanlığı) (1983). İlköğretim, lise ve dengi okullar eğitici çalışmalar yönetmeliği. Tebliğler Dergisi, Say1: 2140. Resmî Gazete: 25.5.1983 / 18057.

MEB. (1995). Millî eğitim bakanlığı sosyal ve kültürel yarışmalar yönetmeliği. Resmî Gazete: 26.12.1995/22505.

MEB. (2005). Millî eğitim bakanlığı ilköğretim ve ortaöğretim kurumları sosyal etkinlikler yönetmeliği. Tebliğler Dergisi, Say1: 2569. Resmî Gazete: 13.1.2005 / 25699.

MEB. (2008). Millî eğitim bakanlığı ilköğretim ve ortaöğretim kurumları sosyal etkinlikler yönetmeliğinde değişiklik yapılmasına dair yönetmelik. Tebliğler Dergisi. Sayı: 2607. Resmî Gazete: 2.3.2008 / 26804.

MEB. (2017). Millî eğitim bakanlığı eğitim kurumları sosyal etkinlikler yönetmeliği. Resmî Gazete: 8.6.2017 / 30090.

Onay, İ., \& Gelen, İ. (2013). İlköğretim okullarındaki eğitsel kulüp uygulamalarının etkililiğine ilişkin öğretmen ve yönetici görüşlerinin değerlendirilmesi. The Journal of Academic Social Science Studies, 6(4), 615-647. https://doi.org/10.9761/JASSS881

Yıldırım, A., \& Şimşek, H. (2016). Sosyal bilimlerde nitel araştırma yöntemleri (10th Bask1). Ankara: Seçkin Yayincilik.

\section{Note}

Note 1. Double-shift schooling: Use of a school twice a day due to the lack of school buildings. Some classes use the building until noon, while the other classes use it in the afternoon. In this way, a whole-day programme is fitted into half a day. Since lesson time is restricted, teaching quality falls. 